\title{
Analysis of Financial Controlling and Statement
}

\author{
Gowtham Chakravarthy, S. Praveen Kumar
}

\begin{abstract}
In the advanced administration, budgetary control is significant. On the off chance that the money related control is powerful, the association will become viable in future. Money related control is one of the presentation control device that are utilized by directors. Authoritative execution is estimated by budgetary control with the centrality of fluctuation. In this exploration, when the budgetary control is insufficient the hierarchical presentation dependent on budgetary control is most exceedingly terrible. What's more, the compelling money related control prompts better authoritative execution. At last, this exploration has demonstrated that there is certain connection between money related control and authoritative execution and there is sure control and connection between budgetary control and hierarchical execution. In this way, It can be finished up the open association should take consideration in the money related control to deal with the exercises adequately.

Keywords: Financial control, organizational performance, Budgetary control
\end{abstract}

\section{INTRODUCTION}

The examination entitled "Investigation OF FINANCIAL CONTROLLING AND STATEMENT" of SAR WORLDWIDE LOGISTICS PVT.LTD is attempted with a goal to consider the monetary presentation and development of the organization, to think about the impact and investigation of budget report and to know the criticalness and execution of the organization through fiscal summary. The instruments utilized for the examination are proportion investigation and relative articulation[1],[3],[5]. A fiscal summary investigation venture helpful in preparer based and client based monetary bookkeeping. The undertaking dissects slants in corporate execution, to assess corporate money related choices, to examine non-budget report issues that would be imperative to potential financial specialists, to look at two organizations inside an industry, and to make speculation proposals. The venture is appropriate to organizations in any industry[2],[4],[6]. The venture requires just restricted presentation, and is effectively versatile to reflect educator inclinations. This paper incorporates the total venture necessity, extra proposals for execution. Through proportion examination the organization could comprehend the benefit, liquidity, influence and turnover places of the firm

Revised Manuscript Received on July 22, 2019

Mr CS. Gowtham chakravarthy, Department of MBA, Bharath Institute of Higher Education and Research, Chennai, India.

Email: chakravins@gmail.com

Dr. S. Praveen Kumar, Department of MBA, Bharath Institute of Higher Education and Research, Chennai, India.

Email: praveenkumar.mba@bharathuniv.ac.in

\section{A. Statement of the problem}

- To discover the varieties in the bookkeeping arrangements

- To assess the elucidation of results[7],[9],[11]

\section{B. Need For the Study}

- To assess an organization's benefit liquidity and dissolvability.

- To make correlations of the consequences of chronicled information, contenders and industry normal execution.

- The relative quality and execution of organization are being dissected[8],[10],[12]

\section{Limitations}

- The study for the most part endeavors to break down the money related execution of the organization.

- It encourages in estimating and to assess the general execution of the organization in future

\section{RESEARCH DESIGN}

The exploration includes the broad and serious investigations of SAR WORLDWIDE LOGISTICS Private Limited to think about the fiscal summary examination of the organization. During this investigation the money related execution and monetary position of the organization is examined. Finally the understanding and finish of the investigation are made[13], [15],[17].

Expressive research configuration was embraced as it tries to break down the budget summary of the organization. Unmistakable research configuration uses components of both quantitative and subjective research ways to deal with build up the what, where and how of a marvel.

\section{A. Method of Data Collection}

The entire investigation depends on the optional information of SAR Worldwide coordinations Private Limited A. The examination does not include any accumulation of essential information. Coming up next are the optional information [14],[16], [18]

1. Statement of Income.

2. Balance Sheet.

3. Statement of Profit and Loss.

4. Cash Flow Statement. 


\section{B. Statistical Tools}

The tools that are used for the study of Analysis of Financial Statement of SAR Worldwide logistics Private Limited

- Ratio analysis.

- Comparative Statement.

\section{Limitations of the Study}

The study is a translation of figures and overlooks the elements, for example, the board style, inspiration of laborers, administration and so on[19],[21],[23].

- The study is influenced by value level changes, deals and execution.

- The study is a translation of figures and overlooks the variables, for example, the board style, inspiration of laborers, administration and so on.

- The study is influenced by value level changes, deals and execution.

Table 1 - Profit Of the Company

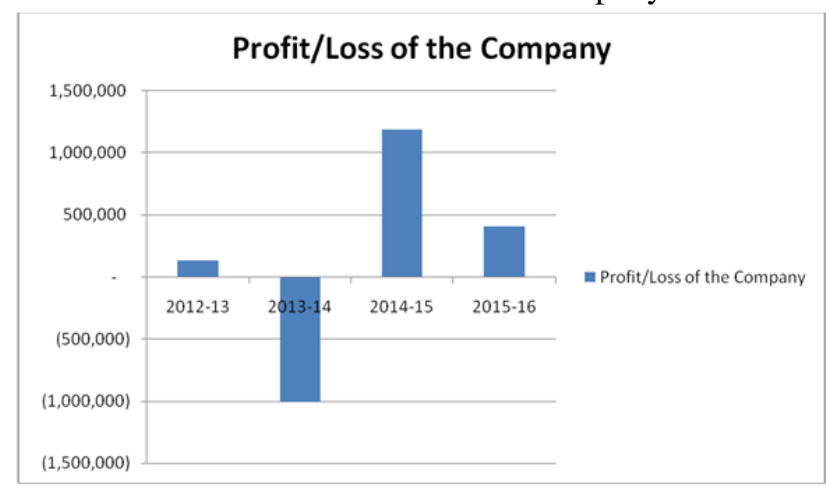

Table 2 - Revenue of the company

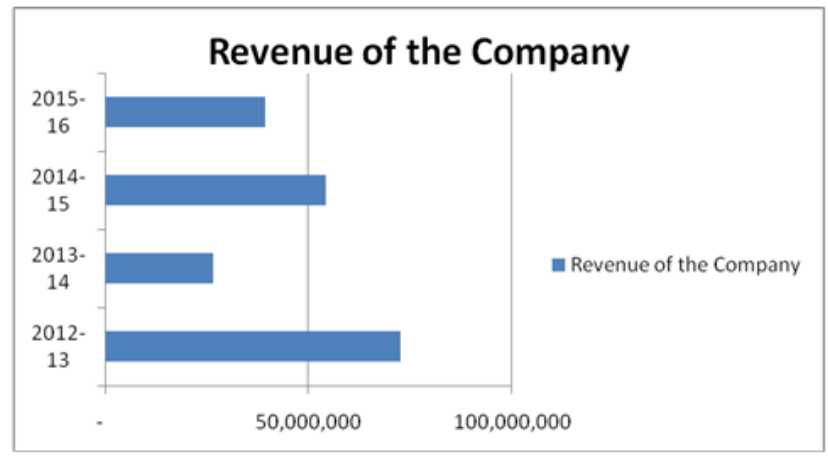

Table 3 - Expenditure of the company

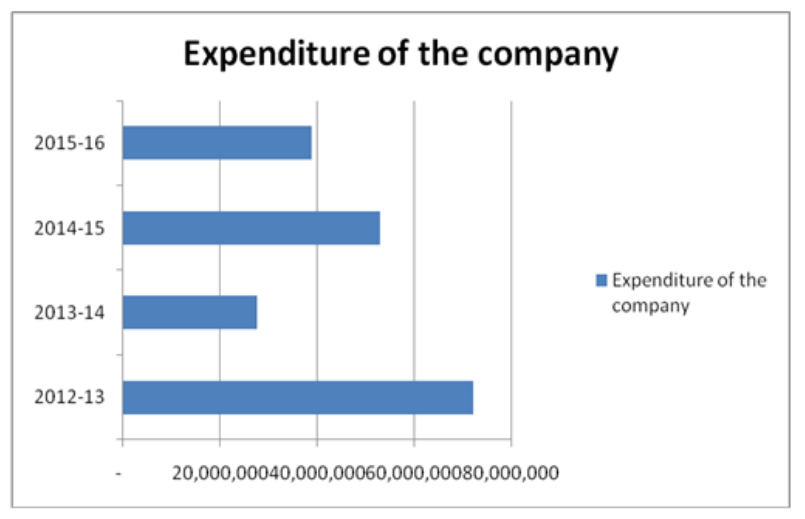

Table 4 - Cash flow of the company

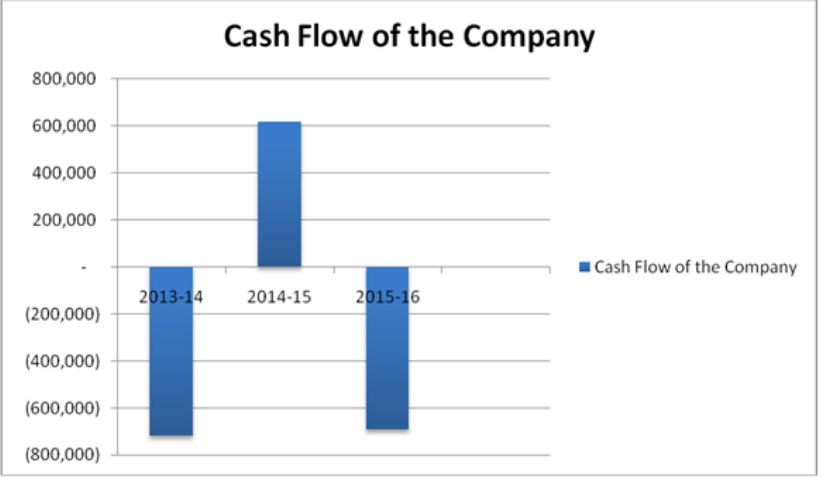

Table 4 - Share Capital of the company

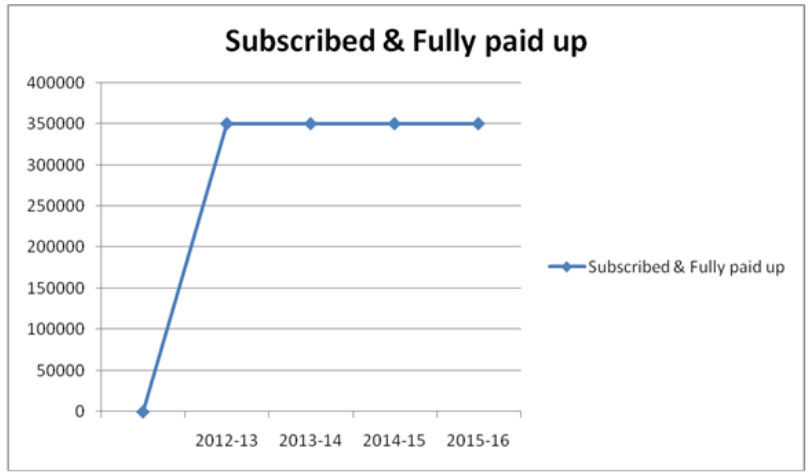

\section{B. Ratio Analysis}

\section{Liquidity Ratios:}

a) Current Ratio

A simple measure that estimates whether the business can pay short term debts. Ideal ratio is $2: 1$. [20],[22],[24]

\section{b) Quick Ratio}

It measures the ability to meet current debt immediately, Ideal ratio is $1: 1$.

c) Cash Ratio

It measures the absolute liquidity of the business.

d) Net Working Capital Ratio

It is a measure of cash flow to determine the ability of business to survive financial crisis. 
Net Working Capital Ratio $=$ Current Assets - Current Liabilities

Table 5 - Current Ratio

\begin{tabular}{|l|l|}
\hline YEAR & CURRENT RATIO \\
\hline $2015-16$ & 1.59 \\
\hline $2014-15$ & 1.53 \\
\hline $2013-14$ & 1.33 \\
\hline
\end{tabular}

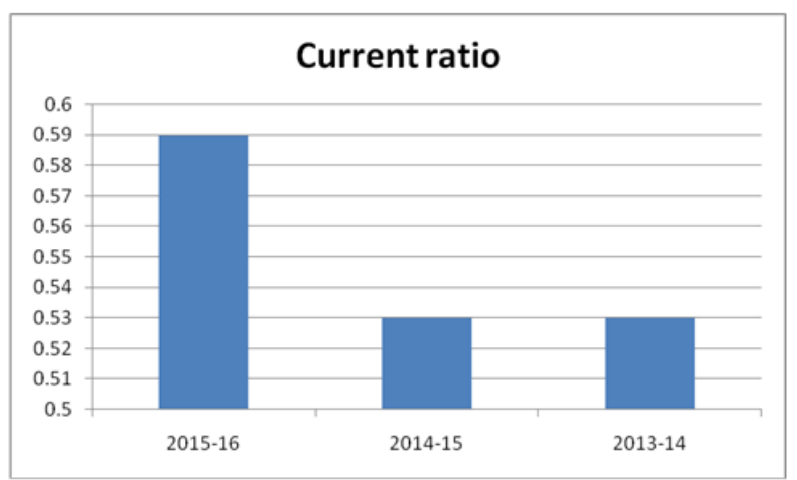

Figure 1 - Current Ratio

Table 6 - Working Capital

\begin{tabular}{|l|l|}
\hline YEAR & WORKINGCAPITAL \\
\hline $2015-16$ & 0.59 \\
\hline $2014-15$ & 0.53 \\
\hline $2013-14$ & 0.53 \\
\hline
\end{tabular}

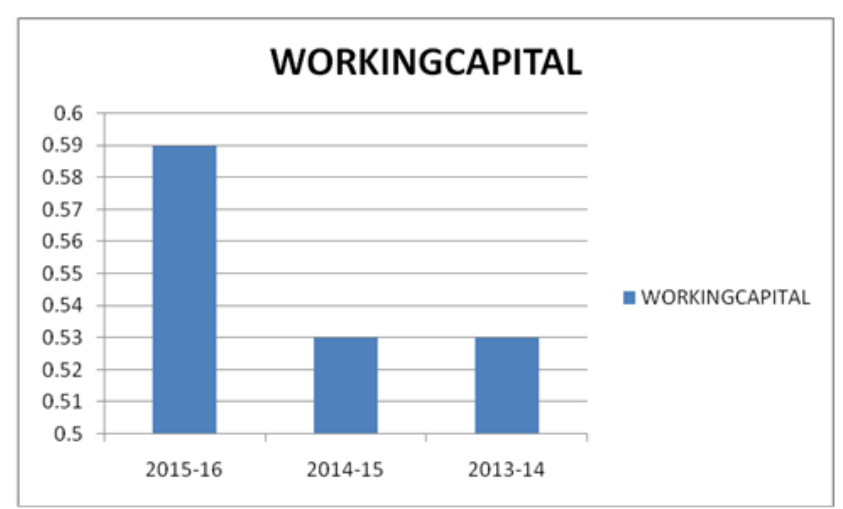

Figure 2 - Working Capital

\section{Leverage Ratios}

1) Capital Structure Ratios

a) Equity Ratio

It indicates owner's fund in companies to total fund invested.

b) Debt Ratio
It is an indicator of use of outside funds.

c) Debt to Equity Ratio

It indicates the composition of capital structure in terms of Debt and Equity.

d)Debt to Total Assets Ratio

It measures how much of total assets is financed by the debt.

e) Capital Gearing Ratio

It shows the proportion of fixed interest bearing capital to equity shareholders fund. It also signifies the advantage of financial leverage to the equity shareholders.

f) Proprietary Ratio

It measures the proportions of total assets financed by shareholders.

Table 7 - Equity Ratio

\begin{tabular}{|l|l|}
\hline YEAR & $\begin{array}{l}\text { EQUITY } \\
\text { RATIO }\end{array}$ \\
\hline $2015-16$ & 0.082 \\
\hline $2014-15$ & 0.091 \\
\hline $2013-14$ & 0.11 \\
\hline
\end{tabular}

\section{EQUITY RATIO}

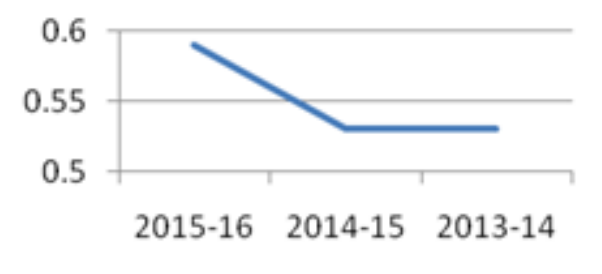

Figure 3 - Working Capital

\section{RESULTS AND DISCUSSIONS}

- The position of benefit can be improved by lessening the different working communicated.

- The use ought to be diminished so as to build the income.

- Cash and bank adjusts ought to be taken consideration

- Share capital can be charge the expanded 
- The current proportion can somewhat expanded and current obligation to be decreased

- The obligation weight of the organization must be observed so as to checked so as to keep up an attractive position. The organization should attempt to keep up fluid money to meet possibilities which will further reinforce the general position of a firm[25],[27],[29]

- The organization is a benefit looking for one; it needs to submit the majority of its assets to accomplish its objective. To accomplish this, benefit, liquidity and dissolvability position a vital components to be checked cautiously, in this manner the exchange off can be come to

- This organization's capacity to meet its present commitments is agreeable despite the fact that it doesn't meet the traditional standard. This organization keeps up current liabilities more than the measure of current resources which must be

seen genuinely and improvement of this proportion is required to accomplish the

ideal level.

- Stock Turnover Ratio ought to be kept up at the consistent level. The Cash and Bank Balances of the organization is great [26],[28],[30]

Using pattern examination it tends to be proposed that the fixed resources bend shows enduring upward course much than the present resources bend, which empower us to comprehend the organization's assets are dumped in fixed resource, it's anything but an ideal condition to the organization.

\section{CONCLUSION}

The general position of the organization can be reinforce and the misfortune position of the organization ought to be fortified. Money related Logistics is consolidated result of coordinations administrations and budgetary administrations. Money related coordinations not just offer our clients high caliber and high-esteem included coordinations and preparing administrations, yet additionally improve the general production network execution and business clients, and capital effectiveness for customers of the monetary administrations straightforwardly or by implication. [31],[33] As per the creator of budgetary organizations, (for example, banks) in differing degrees, the money related coordinations incorporates resources course model, capital stream model and coordinated resource model. In spite of the fact that the advancement of the monetary coordinations suppliers give money related coordinations, production network hubs undertakings and budgetary organizations create win-win results, the supplier needs to confront an assortment of dangers.

\section{REFERENCES}

1) BharthVajan R., Ramachandran S.,Psychographic dimensions of training,2016,International Journal of Pharmacy and Technology,V-8,I-4,P-23727-23729

2) Balakrishnan P., Bharthvajan R.,A study on human resource planning in hospitals in Chennai City,2014,International Journal of Applied Engineering Research,V-9,I-22,P-7503-7507

3) Priyadarsini P., Bharthvajan R.,Role of emotional intelligence training programme in reducing the stress of the nurses,2014,International Journal of Applied Engineering Research,V-9,I-22,P-7411-7421

4) Kerinab Beenu G., Bharthvajan R.,Empirical analysis on the cosmetic buying behavior of young women in South India,2014,International Journal of Applied Engineering Research,V-9,I-22,P-7361-7366

5) Balakrishnan P., Bharthvajan R.,Whistling in the wind,2014,International Journal of Applied Engineering Research,V-9,I-22,P-7586-7593

6) Krishnan B., Peter M.,Health hazards of Indian Bpo employee-an alarming issue,2014,International Journal of Applied Engineering Research,V-9,I-22,P-7336-7341

7) Kerinab Beenu G.H., Peter M.,Role of insurance in economic development,2014,International Journal of Applied Engineering Research,V-9,I-22,P-7532-7539

8) Balakrishnan P., Peter M., Priyadarsini P.,Efficiency of safety measures for wellbeing of employees in manufacturing industry,2014,International Journal of Applied Engineering Research,V-9,I-22,P-7376-7382

9) Anbarasi M., Praveen Kumar S.,Online sales promotions of herbal products and its effectiveness towards tanisha.com,2019,Indian Journal of Public Health Research and Development,V-10,I-1,P-195-200

10) Anbarasi M., Praveen Kumar S.,Various online marketing and promotions strategies to improve the validation towards the organic products in the pharmaceutical sectors,2019,Indian Journal of Public Health Research and Development,V-10,I-1,P-263-269

11) Loganathan R., Praveen Kumar S.,Grievance handling a key factor for solving issues of employees in an organization,2014,International Journal of Applied Engineering Research,V-9,I-22,P-7483-7491

12) Loganathan R., Praveen Kumar S.,Study on preference of private label brands in super and Hypermarkets,2014,International Journal of Applied Engineering Research,V-9,I-22,P-7327-7335

13) Smitha M., Praveen Kumar S.,Understanding stress and its managementamong the nurses in Chennai city,2014,International Journal of Applied Engineering Research,V-9,I-22,P-7560-7565

14) Kerinab Beenu G.H., Praveen Kumar S.,A study on the investment behavior of Chennai investors in mutual fund schemes,2014,International Journal of Applied Engineering Research,V-9,I-22,P-7520-7525

15) Loganathan R., Praveen Kumar S.,Retention strategies key for organizational productivity,2014,International Journal of Applied Engineering Research,V-9,I-22,P-7443-7447

16) Pavithra J., Ganesan M., Brindha G.,State wise analysis of microfinance sector in India,2016,International Journal of Pharmacy and Technology,V-8,I-4,P-23417-23432

17) Pavithra J., Ganesan M.,A comparative study on microfinance in India and abroad,2016,International Journal of Applied Business and Economic Research,V-14,I-8,P-5471-5476

18) Pavithra J., Ganesan M.,A study on awareness and impact of micro-financial schemes,2016,International Journal of Applied Business and Economic Research,V-14,I-8,P-5449-5460

19) Senthilmurugan P., Pavithra J.,Consumer preference towards organised retailing with reference to Big Bazaar,2014,International Journal of Applied Engineering Research,V-9,I-22,P-7469-7475

20) Senthilmurugan P., Pavithra J.,Implication of social media marketing in growing healthcare industry,2014,International Journal of Applied Engineering Research,V-9,I-22,P-7448-7456

21) Loganathan R., Pavithra J.,Consumer perception towards private label brand over other brands in super markets and hypermarkets,2014,International Journal of Applied Engineering Research,V-9,I-22,P-7355-7360

22) Kerinab Beenu G., Pavithra J.,Tradeâ€"off between liquidity and profitability in logistics industry,2014,International Journal of Applied Engineering Research,V-9,I-22,P-7398-7401

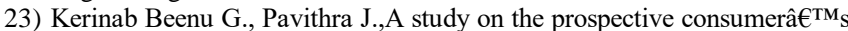
perception towards utility cars in Chennai city,2014,International Journal of Applied Engineering Research,V-9,I-22,P-7526-7531

24) Pavithra J., Dilli Babu P., Ambuli T.V.,A study on budgetary control at Maruti Service Masters, Chennai,2014,International Journal of

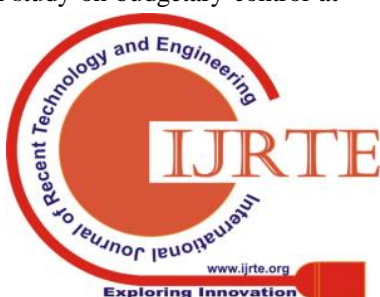


Applied Business and Economic Research,V-12,I-2,P-151-161

25) Pavithra J., Dilli Babu P., Ambuli T.V.,A study on customer satisfaction of retro Garments Pvt Ltd, Chennai,2014,International Journal of Applied Business and Economic Research,V-12,I-2,P-381-391

26) Kerinab Beenu G.H., Pavithra J., Senthilmurugan P.,A study on the influence of promotional activities for TATA ARIA among consumers in Chennai,2014,International Journal of Applied Engineering Research,V-9,I-22,P-7572-7578

27) Vijayaragavan S.P.,An investigative expert that's general FBG sensors,International Journal of Mechanical Engineering and Technology,V-8,I-8,PP-1500-1505,Y-2017

28) Vijayaragavan S.P.,Equalization routing protocol for Wi-Fi sensor strategy,International Journal of Mechanical Engineering and Technology,V-8,I-8,PP-1662-1666,Y-2017

29) Karthik B., Kiran Kumar T.V.U., Vijayaragavan P., Bharath Kumaran E.,Design of a digital PLL using 0.35 $\hat{\mathrm{I}}^{1 / 4 \mathrm{~m}}$ CMOS technology,Middle East Journal of Scientific Research,V-18,I-12,PP-1803-1806,Y-2013

30) Kanniga E., Selvaramarathnam K., Sundararajan M.,Kandigital bike operating system,Middle - East Journal of Scientific Research,V

31) Jasmin M., Vigneshwaran T., Beulah Hemalatha S.,Design of power aware on chip embedded memory based FSM encoding in FPGA,International Journal of Applied Engineering Research,V-10,I-2,PP-4487-4496,Y-2015

32) Jasmin M.,Optimization techniques for low power VLSI circuits,Middle East Journal of Scientific Research,V-20,I-9,PP-1082-1087,Y-2014

33) Jasmin M., Vigneswaran T.,Fuzzy controller for error control of on - Chip communication,2017 International Conference on Algorithms, Methodology, Models and Applications in Emerging Technologies, ICAMMAET 2017,V-2017-January,I-,PP-1-5,Y-2017

\section{AUTHORS PROFILE}

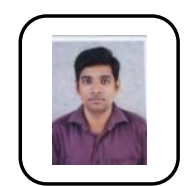

Mr CS. Gowtham chakravarthy Assistant Professor, Department of MBA, Bharath Institute of Higher Education and Research, Chennai, India.

Dr. S. Praveen Kumar Professor, Department of MBA, Bharath Institute of Higher Education and Research, Chennai, India. 